MARCIN MUSIAŁ

Uniwesytet Wrocławski

\title{
ODRODZENIE NAMYSŁOWSKIEGO KLASZTORU FRANCISZKAŃSKIEGO W XVII WIEKU W ŚWIETLE PIERWSZEGO ROZDZIALU KRONIKI KONWENTU
}

\author{
Nach diesen wir in das Closter gangen, und weiters in die \\ Kirchen, allwo Herr Ertz-Priester das Te Deum laudamus \\ intoniert, welches hernach die Musicanten mit Trompeten \\ und anderer music continuiret ${ }^{\mathrm{I}}$.
}

Kiedy 8 października I675 r. dźwięki pochwalnych hymnów śpiewanych przez braci reformatów ${ }^{2}$ wypełniały namysłowski kościół pw. Wniebowzięcia Najświętszej Maryi Panny, kończył się trwający przeszło dwie dekady spór o odzyskanie tamtejszych obiektów franciszkańskich. Rozbudowany ceremoniał przekazania kluczy i wszelkiej dokumentacji potwierdzającej prawa wspólnoty do obejmowanych obiektów, z udziałem lokalnych oficjeli, władz zakonnych oraz miejscowych wiernych, o czym wspomina chociażby fragmentarycznie zacytowana powyżej relacja jednego z cesarskich komisarzy, poprzedziły liczne spory i zmagania prowadzone drogą dyplomatyczną, angażujące zarówno władze miejskie, zakonne jak i królewskie. Aby bowiem odzyskać obiekty, co do których roszczono sobie prawa, należało przed majestatem władcy przedstawić stosowny, pełny wywód historyczno-prawny, będący merytoryczną podstawą dla wydania ostatecznej decyzji w procesie restytucyjnym. Bracia przeszukiwali zatem prowincjalne archiwa, kroniki zakonne i miejskie, instrumenty

\footnotetext{
1 S. Wrbczansky, Nucleus minoriticus: seu vera, \& sincera relatio originis, \& progressus Provincice Bohemice, Conventuum, et Residentiarum, Fratrum, \& Sororum Sancti-Monalium, Ordin. Minor. S.P. Francisci Strict. Observ. Reform. in Provincia, sub patrocinio Sancti Wenceslai ducis, \& martyris, per Bohemiam, Moraviam, \& Silesiam existentium..., Vetero-Pragae 1746, s. 307.

2 Kwestią, której zaznaczenie w pewien sposób ułatwi poruszanie się po tematyce śląskich franciszkanów, jest nomenklatura. Franciszkanów tzw. Pierwszej formacji określam, jak jest to czynione w literaturze i źródłach, minorytami. Na przełomie XV i XVI w. uformowała się w łonie zakonu jego nowa gałąź odznaczająca się dążeniem do przestrzegania ściślejszej obserwancji. W 1517 r. zakon franciszkański (określany dotychczas mianem minorytów) uległ podziałowi na tym tle, w wyniku czego powstały dwie odrębne formacje: stanowiący formę kontynuacji gałęzi minorytów Bracia Mniejsi Konwentualni oraz Bracia Mniejsi Obserwanci (zwani często również bernardynami). Jednocześnie, od 1528 r. powołany został, również jako osobny, zakon Braci Mniejszych Kapucynów. To jednak, co z punktu widzenia moich rozważań jest istotne, to przemiany, również w warstwie językowej, jakie zaszły w XVI i XVII w. w zakonie Braci Mniejszych Obserwantów. Wskutek rozwoju działań na rzecz wprowadzenia reformy ukierunkowanej na powrót do ideałów św. Franciszka w zakresie ubóstwa, wydzieliła się z tej gałęzi zakonu wspólnota określona mianem Braci Mniejszych Ściślejszej Obserwancji. Wśród nich funkcjonowało i rozwijało się kilka grup, zróżnicowanych w zakresie nazw głównie na zasadzie geograficznej, m.in. rekolekci, dyskalceaci i reformaci. To właśnie ci ostatni, poprzez przyjęcie przez całą obserwancką dotychczas prowincję czeską nowych, zreformowanych statutów w 1660 r. przybyli do Namysłowa w 1675 r.
} 
czy nadania, by po wypisaniu informacji odpowiednio potwierdzających prawo własności, przedłożyć je w skondensowanej formie delegatum iudicium w charakterze argumentu w postępowaniu procesowym³ .

Niniejsze opracowanie ma na celu z jednej strony zarysowanie okoliczności powstania namysłowskiego konwentu reformatów w I675 r., z drugiej zaś zwrócenie uwagi na sposób prowadzenia narracji historiograficznej w reformackich źródłach kronikarskich. Swoistym przewodnikiem po meandrach tego fragmentu dziejów klasztoru, jak i transparentnym dla samego zjawiska ukazywania historii zakonu przykładem, uczyniłem kronikę konwentu namysłowskiego, której oryginał znajduje się we wrocławskim oddziale Archiwum Państwowego. Jej pierwszy rozdział zatytułowany Chronicon de origine conventus hujus ad $S$. Petrum de Alcantara zawiera opis działań czynionych przez zakon w celu odzyskania po wojnie trzydziestoletniej utraconego wskutek reformacji kompleksu, i przytacza, jak mniemam w roli argumentów, wcześniejsze dzieje placówki. Wybrane zatem przez kronikarza fakty, jak również sposób ich prezentacji, pozwalają odczytywać się na płaszczyźnie nieco szerszej aniżeli tylko faktograficznej. Wprowadzają bowiem kluczowe w postępowaniu rewindykacyjnym obszary konfliktowe - od sięgających czasów średniowiecza sporów wewnątrzzakonnych, po ugruntowane w okołoreformacyjnych przemianach mentalnych społeczności miast śląskich zatargi z magistratem, czy w końcu, wydawałoby się najistotniejsze, kwestie drażliwe $\mathrm{z}$ konfesyjnego punktu widzenia.

Wybór źródła pozwolił na nieco dokładniejsze sprecyzowanie cezur na lata I675-I678. Jest to bowiem rok powrotu reformatów do klasztoru w Namysłowie oraz rok powstania kroniki autorstwa o. Bernarda Sanniga, będącej owocem wizytacji prowincji, która, jak wskażę poniżej, pozostaje w silnej zależności z kroniką konwentu. Naturalnie, zgodnie $z$ retrospektywnym charakterem kronikarskiego zapisu, najwcześniejsze wydarzenia przywoływane $\mathrm{z}$ dziejów klasztoru sięgają czasów średniowiecznych, kluczowy jednak, jak sądzę, jest w tym momencie punkt, z którego kronikarz opisywał przeszłość. Wydaje się zatem, że takie zawężenie chronologiczne pozwoli zobaczyć badany obiekt w pierwszej fazie jego odbudowy, zarówno materialnej jak i duchowej, w postaci odrodzenia konwentu i przywracania go w przestrzeni kulturowo-społecznej Namysłowa.

Kontynuując nakreślanie kontekstu, w jakim powstało kluczowe dla niniejszej pracy źródło, warto, rozwiewając wszelkie wątpliwości, zwrócić się ku wspólnocie odpowiedzialnej za jego powstanie. Zakon Braci Mniejszych Reformatów (OFM Ref) ${ }^{4}$, kształtowany od drugiej poł. XVI w., wyłonił się z obserwanckiego nurtu reformistycznego w ramach wydzielonego W 1517 r. z rodziny franciszkańskiej Zakonu Braci Mniejszych Obserwantów. Osią, wokół której formowała się reformacka wspólnota, była idea odnowy życia zakonnego w duchu ściślejszego przestrzegania reguły zakonnej, powrotu do źródeł i pierwotnego ubóstwa franciszkańskiego. Praktyka życia reformackiego sprowadzała się w swym ogólnym oglądzie do próby połączenia pustelniczego i ukierunkowanego na kontemplację życia w odosobnieniu z szeroko rozumianym apostolatem.

\footnotetext{
3 K. Minarik, Bernard Sannig, učenec, spisovatel a organizátor františkánské provincie (1637-1704), ,, Časopis katolickeho duchovenstva", 64 (89), 1923, 5, s. 24.

4 A. Wiśniowski, Bracia Mniejsi Ściślejszej Obserwancji, w: Encyklopedia katolicka, t. V, Lublin 1989, k. 486488; R. Sbardella, Bracia Mniejsi Reformaci w XVI- XVIII wieku, w: Zakony franciszkańskie w Polsce, t. 2, Franciszkanie w Polsce XVI-XVIII wieku, cz. 1, red. H. Gapski, C. Napiórkowski, Niepokalanów 1998, s. 58-79.
} 
Należy jednocześnie podkreślić, że pod względem prawno-administracyjnym reformaci nie stanowili odrębnego zakonu, lecz, mając ugruntowaną w XVII w. autonomię, byli wraz $\mathrm{z}$ innymi wspólnotami reformowanymi (dyskalceaci, rekolekci) ${ }^{5}$ częścią wspólnego zakonu braci mniejszych obserwantów. Wprowadzało to konieczność partycypacji w życiu ogólnozakonnym poprzez udział w kapitułach generalnych, uznanie zwierzchnictwa generała czy przyjęcie statutów generalnych, co łączono z wprowadzaniem na poziomie regulacji partykularnych zróżnicowań w postaci niezależnych statutów prowincjalnych czy własnej sieci prowincji.

W czeskiej prowincji obserwanckiej praktycznie od początku XVII w. bracia coraz liczniej opowiadali się za wewnątrzzakonną odnową i stopniowo kolejne konwenty z obserwanckich stawały się reformackimi. Proces ten doprowadził w I660 r. do przekształcenia dotychczasowej czeskiej prowincji obserwanckiej w reformacką, pod patronatem św. Wacława, która obejmowała klasztory reformatów położone na obszarze Czech, Moraw i Śląska ${ }^{6}$.

Proces ten skorelowany był z sukcesywnym dążeniem władz zakonnych do odzyskania opuszczonych bądź odebranych w dobie reformacji klasztorów i kościołów. Sprzyjała temu wyraźna protekcja katolickiego dworu habsburskiego, który upatrywał w odnowionych w duchu postanowień soboru trydenckiego zakonach narzędzia umożliwiającego realizację działań rekatolicyzacyjnych, mających docelowo doprowadzić poprzez unifikację wyznaniową do stworzenia silnego, stabilnego państwa rządzonego przez arcykatolickiego władcę.

Odwołując się zatem do królewskiej instancji, bracia mniejsi praktycznie przez cały XVII w. na drodze sądowej odzyskiwali dawne mienie, zakładali nowe placówki, a przez to odbudowywali struktury prowincji czeskiej ${ }^{7}$. Proces ten przybrał na sile w sposób szczególny podczas prowincjalatu o. Bernarda Sanniga, w latach I675-I678 i I684-I687 ${ }^{8}$. Na czas pierwszego ministrowania Sanniga przypadł proces zwieńczony restytucją klasztoru w Namysłowie, który był 22. w kolejności reaktywowaną po reformacji placówką w prowincji.

\section{Charakterystyka źródła}

Materiał źródłowy pozwalający zbadać nowożytne dzieje franciszkańskiego konwentu w Namysłowie wydaje się być zadowalająco obfity. Składają się niego przede wszystkim

\footnotetext{
5 Dla odróżnienia od obserwantów (zwanych również bernardynami) określano zbiorczo te wspólnoty mianem braci mniejszych ściślejszej obserwancji.

6 Śląskie klasztory reformackie wchodziły w skład czeskiej prowincji reformackiej św. Wacława z siedzibą w Pradze, obejmującej obszar praktycznie całego Królestwa Czeskiego (Czechy, Morawy, Śląsk). Powstała w 1660 r. na drodze przyjęcia przez dotychczas obserwancką prowincję św. Bernardyna zreformowanych statutów. Oprócz czeskich reformatów na Śląsku powstały również dwa klasztory przynależące do polskich prowincji reformackich na Górze św. Anny i w Gliwicach. W obręb czeskiej prowincji św. Wacława wchodziły klasztory w: Nysie (1620 r.), Jaworze (1638 r.), Kłodzku (1639 r.), Głogowie (1640 r.), Głubczycach (1666 r.), Namysłowie (1675 r.), Wrocławiu (1678 r.), Raciborzu (1686 r.), Legnicy (1700 r.) i Złotoryi (1704 r.). W 1755 r. wskutek przemian politycznych roku 1741, z czeskiej prowincji wydzielone zostały klasztory śląskie tworzące od tego czasu aż do sekularyzacji w 1810 r. śląską prowincję św. Jadwigi. Obejmowała ona znów tylko wymienione 10 klasztorów, bez Góry św. Anny i Gliwic. L. Teichmann, Ordensprovinzen der Franziskaner in Schlesien, „Archiv für schlesische Kirchengeschichte”, 43, 1985, s. 263-274; Ch Reisch, Die Franziskaner im heutigen Schlesien von Anfange des 17. Jahrhunderts bis zur Säkularisation, „Zeitschrift des Vereins f. Gesch. Schlesiens”, 47, 1913, s. 276-300.

7 M. Elbel, Česka františkanska province sv. Vaclava (1570 - 1790), „Acta Universitatis Palackianae Olomucensis. Facultas Philosophica. Historica", 29, 2000, s. 83-96.

8 K. Minarik, Bernard Sannig, učenec, spisovatel a organizátor františkánské provincie (1637-1704), „Časopis katolickeho duchovenstva", R. LXI (LXXXVI) 1920 - R. LXXI (LXLVI) 1930.
} 
przechowywane w praskim Národni Archiv (Archiwum Państwowe) jednostki dotyczące placówki namysłowskiej w zespole Archiv české františkánské provincie. Obejmuje on dziewięć teczek z archiwaliami zawierającymi m.in. inwentarze biblioteczne i kościelne, dzieje klasztoru uwzględniające postępowanie rewindykacyjne, spory własnościowe czy jałmużny i nadania9. Ponadto źródłem bezpośrednio związanym z klasztorem w Namysłowie jest kronika konwentu, a właściwie jej kopia sporządzona dla władz prowincji, obejmująca lata I675-I755, a więc okres funkcjonowania konwentu namysłowskiego w granicach czeskiej prowincji franciszkanów reformatów pw. św. Wacława. Główna, jak się wydaje, kronika konwentu przechowywana jest we wrocławskim oddziale Archiwum Państwowego w zespole Rękopisów archiwalnych pod tytułem Archivum Conventus Namslaviensis Ord. Min. S. P. Francisci Reform. Erectum Anno $1675^{\mathrm{I0}}$. Jest to oprawny w skórę z okuciami kodeks łacińsko-niemiecki o wymiarach 33,5 x $23 \mathrm{~cm}$, w którym na 202 stronicach, podzielonych na rozdziały, zapisano dzieje konwentu reformackiego w Namysłowie od momentu jego założenia w I675 r. aż do końca XVIII w. " Zarówno w zakresie układu treści, jak i rodzaju zapisywanych informacji odpowiada zachowanym kronikom pozostałych klasztorów braci mniejszych na Śląsku, do których prowadzenia obligowały konwenty reformackie statuty prowincjalne. Prócz opatrywanych poszczególnymi datami wydarzeń z życia konwentu, dziejów budowy klasztoru i kościoła czy adnotacji o donatorach, kronika zawiera także odpisy istotniejszych w oczach twórców dokumentów z czasu powstania i funkcjonowania placówki (reskrypty cesarskie, listy fundacyjne czy umowy transakcyjne z radą miejską).

Trudno jednoznacznie wskazać autora kroniki. Widoczne są różnice w charakterze pisma pozwalające podzielić okres powstawania kodeksu przynajmniej na dwie części. Symptomatyczna wydaje się zgodność treści pierwszego rozdziału dzieła z odpowiednim passusem dotyczącym Namysłowa w sporządzonej ok. I678 r. kronice prowincji czeskiej autorstwa wspominanego wyżej o. B. Sanniga ${ }^{12}$. Pierwotnie przypuszczałem, że to właśnie kronika namysłowska stała się fundamentem pracy Sanniga, a w następstwie większości późniejszych opracowań historycznych klasztoru w Namysłowie ${ }^{13}$. Zakładałem, że Sannig, przeprowadzając wizytację, spisywał w archiwach poszczególnych klasztorów wprowadzające rozdziały kronik dotyczące dziejów osadzania reformatów w poszczególnych miastach ${ }^{\mathrm{I}}$. Koncepcję tę zaburzyła jednak nota kończąca interesujący mnie w sposób szczególny w niniejszym opracowaniu fragment pierwszego rozdziału kroniki namysłowskiej: Composuit

\footnotetext{
9 Opis zespołu: M. Wójcik, Sprawozdanie z kwerendy w Pradze w dniach 17-23 IX 2012 r., „Hereditas Monasteriorum", 1, 2012, s. 468.

10 Archiwum Państwowe Oddział we Wrocławiu (dalej: APWr), Zbiór rękopisów archiwalnych (dalej: Rep. 135), D 227, mf T78753, Archivum Conventus Namslaviensis Ord. Min. S. P. Francisci Reform. Erectum Anno 1675 (dalej: Chronica).

11 Ostatnie wpisy pochodzą z $1798 \mathrm{r}$.

12 Narodni Archiv Praha (dalej: NA Praha), Archiv české františkánské provincie (dalej: RF), 409, kodeks 17 (dalej: k. 17), Bernard Sannig, Chronica de origine et constitutione Provinciae Bohemiae Ordinis Fratrum Minorum S. Francisci Reformatorum, eiusdemque conventuum. Ab Anno 1224 usque 1678. Kopia kroniki znajduje się również we Wrocławiu: APWr, Rep. 135, D 41a, mf T 78730, B. Sannig, Chronica.

13 Opracowanie Sanniga stało się następnie podstawą dla dwóch XVIII-wiecznych prac zbierających informacje o wszystkich klasztorach franciszkańskich na ziemiach niemieckich: S. Wrbczansky, op. cit.; V. Greiderer, Germania franciscana: seu chronicon geographo-historicum ordinis S.P. Francisci in Germania..., Oeniponte 1777. Prace te uzupełniają zapiski Sanniga o edycję wybranych dokumentów fundacyjnych czy transakcyjnych oraz lapidarne opisy kościołów i klasztorów, czasem również prostując pewne podane u niego informacje (Greiderer).

14 Analogiczna sytuacja miała miejsce w przypadku kroniki wrocławskiego konwentu św. Antoniego.
} 
haec veridico calamo Fr. Bernardus Sannig pro tempore Minister Provincialis Anno I678 ${ }^{15}$. Zgodnie z powyższymi uwagami analogiczny zapis występuje w kronice prowincji. Wydaje się zatem, że albo sam Sannig napisał wstęp kroniki namysłowskiej, albo jej twórca, przepisawszy z kroniki Sanniga „namysłowski” fragment, odpowiednio wskazał jego autorstwo. Analizując charakter pisma obu źródeł, widać, iż nie zostały napisane jedną ręką. Co więcej, pewne różnice w dukcie pisma i charakterze kreślenia wybranych liter widać również przy porównaniu kroniki wrocławskiej i jej kopii praskiej. Pozwala to wykluczyć wspólne autorstwo, nie wnosi jednak wiele w dokładnym datowaniu kodeksów. Pozostając jednak na gruncie autorstwa kroniki konwenckiej przechowywanej we Wrocławiu, w praskim zespole archiwalnym w teczce Dzieje klasztoru znajduje się kolejna, analogiczna nota, określona jeszcze przez zakonnego archiwistę jako Descriptio Historica Conventus Namslaviensis S. R. P. Bernardus Sannig, cui audit Alid Chronicon urbis et Conventus ${ }^{16}$. Nadany tytuł stawia pod znakiem zapytania kolejność powstawania poszczególnych rękopisów, a zatem kroniki konwentu z Pragi i Namysłowa, kroniki Sanniga oraz wymienianej jako ostatnia, notatki.

Jak zatem zaznaczałem wcześniej, główną osią niniejszego opracowania uczyniłem czterostronicowy fragment pierwszego rozdziału kroniki konwentu franciszkanów reformatów w Namysłowie, opisujący w układzie chronologicznym dzieje powstania klasztoru w XVII w. Wybrałem fragment wspólny dla kronik konwentu i prowincji, jak również wspomnianej notatki autorstwa Sanniga.

Fragment ów podzielić można na trzy zasadnicze części, z których pierwsza opisuje przebieg zarówno starań braci o odzyskanie klasztoru, jak i wcześniejsze dzieje placówki, od jej założenia w I32I r., przez zmiany przynależności prowincjalnej oraz reformację aż po sławetny rok I675. To właśnie wydarzenia tego roku oraz dwóch po nim następujących wyznaczają drugą część. Składają się na nią opisy ceremonii przekazania kościoła i klasztoru franciszkanom wraz z przywołaniem odpowiednich dokumentów potwierdzających prawa zakonników do namysłowskiej placówki. Ostatnią część stanowi lapidarny, jednostronicowy opis obiektów sporządzony w okresie konsekracji świątyni, zakończony cytowaną adnotacją o autorstwie. Poniżej przytaczam omawiany tekst w „wolnym” tłumaczeniu, odpowiednio opatrując go odwołaniami do łacińskiego oryginału.

Zgodnie z treścią zapisu, początki namysłowskiego klasztoru franciszkańskiego związane są ze sporządzonym przez śląskiego księcia Konrada, pana oleśnickiego i namysłowskiego, dokumentem, mocą którego bracia otrzymywali grunt w granicach jurydyki książęcej na terenie miasta, gdzie mogli wznieść klasztor i kościół. Zgodnie z kroniką obiekty te wybudowano dzięki ofiarom składanym przez wiernych mieszczan. Instrument wystawiono w Namysłowie w wigilię wspomnienia świętych apostołów Filipa i Jakuba roku I32 $^{17}$.

15 APWr, Rep. 135, D 227, mf T78753, Chronica, s. 7.

16 NA Praha, RF, 3047.

17 Qvemadmodum vetustum docet instrumentum In Archivo Provinciae reconditum, qvod incipi: "Noverint Universi tenorem praesentium, etc:" datum Namslaviae, in vigilia SS. Apostolorum Philippi et Jacobi,/ Anno 1321. Fratres Minores anno memorato in Civitate Namslaviensi /: qvae est sub Dioecesi Wratislaviensi ad confinia Poloniae sita:/ a Conrado Duce Silesiae, Domino in Öls, et Namslau, obtinuerunt fundum, ab Eodem Duce Ordini donatum, cui moles vasta Ecclesiae et Conventus competentis superaedificata fuit ex communibus Christi Fidelium eleemosynis; APWr, Rep. 135, D 227, mf T78753, Chronica, s. 4/1. 
Bracia mniejsi, na kartach kodeksu określeni mianem Patres Conventuales, przebywali w klasztorze aż do I5ı r. kiedy Władysław, król Czech i książę śląski, przedłożył magistratowi namysłowskiemu swoją decyzję o usunięciu z klasztoru braci konwentualnych przynależących do prowincji saskiej na rzecz franciszkanów obserwantów z prowincji czeskiej, których dodatkowo należało otoczyć odpowiednią opieką ${ }^{\mathrm{I}}$. Jak zaznaczył autor, quod et factum est. Decyzję władcy potwierdzić miał następnie mocą wydanej 29 listopada I523 r. bulli Romani Pontificis Providentia papież Klemens VII, jak również franciszkańska kapituła generalna w Burgos z tego samego roku. Dodatkowo, następca Władysława, Ludwik wystawił kolejny dokument o podobnej treści skierowany do ówczesnego starosty Śląska Fryderyka księcia legnickiego i brzeskiego, który, wydany w Pradze, rozpoczynały słowa: Cum Dilecti Fideles.

Obserwanci przebywać mieli w namysłowskim klasztorze do roku i536, kiedy wskutek toksycznej działalności sekty luterańskiej wśród obywateli miasta, bracia tracili stopniowo możliwość utrzymania się ze zmniejszających się ofiar, co łączyło się ze spadkiem liczby powołań. W konsekwencji zatem kompleks został opuszczony, zaś w budynku klasztornym zorganizowano szpital dla ubogich, działający do I675 r., kiedy prowincja czeska odzyskała namysłowskie obiekty, przywracając działalność franciszkańskiego konwentu ${ }^{19}$.

W tymże roku przybył do Namysłowa o. Theophilus May wraz z dwoma innymi duchownymi franciszkańskimi, gdzie przez wiele miesięcy przebywali w domu Laurentiusa Joannstona, określonego w kronice jako Admodum Reverendus Dominus Archi Presbiterus et Curatus Namslaviensis, który otoczył braci gościnną opieką i wsparciem. Reformaci korzystali z gościnności gospodarza do czasu, kiedy o. B. Sannig, ówcześnie sprawujący posługę prowincjała oraz definitora generalnego, otrzymał decyzję cesarza Leopolda I przedstawioną w wydanej w Wiedniu z dniem 2I września I675 r. rezolucji rozpoczynającej się słowami: Wir gaben aus eurem gehorsamen Brieff etc. Mocą tego dokumentu prowincja czeska otrzymywała na powrót klasztor w Namysłowie. Restytucja stała się faktem kiedy 8 października I675 r., którego (roku) odrzucono pretensje Ojców Konwentualnych, o godzinie 9:00 rano o. Patritius Pallet, będący delegatem o. Sanniga, wraz z o. T. Mayem (protogwardianem) i czterema towarzyszami uroczyście zostali wprowadzeni do kościoła NMP i klasztoru (ku czci św. Piotra potem mianowany przez wspomnianego o. prowincjała Sanniga). Aktu przekazania obiektów dokonało dwóch cesarsko-królewskich komisarzy, deputowanych śląskiego Urzędu Zwierzchniego: kanonik katedry wrocławskiej Caspar Heinrich von Oberg oraz Andreas Friedrich, których zaprowadzono na przykościelny cmentarz, gdzie odczytany

18 [..] In qvibus commorati sunt Patres Conventuales usqve ad Annom 1510 qvo Serenissimus Rex Bohemiae, et Silesiae Dux Wladislaus transmisit Decretum mandatorium Magistratui Namslaviensi, ut Expedia Conventualibus Provinciae Saxoniae, Patres Observantes Provinciae Bohemiae In Regularem Ecclesiam, et Coenobium Franciscanum, foveant Eosdem, protegantqve, qvod et factum est. APWr, Rep. 135, D 227, mf T78753, Chronica, s. 4/1.

19 At modico tempore videlicet usque ad Annum 1536. ibidem substitere, quando toxicum lutheranae sectae Namslavienses Penates qvoqae infecit, usquae adeo, ut fide cum Orthodoxa subtractis qvotidianis eleemosynis, sensim extingverentur incola Regulares, et nullis novis subsequentibus Domicilium hoc Religiosum tandem evacuaretur, atquae in Hospitale pauperum posthac conversum usquae ad Annum 1675 /: quo Provincia nostra Boemiae animum rursum adjecit locum hunc suum Regularem ressumendi:/ lugeret., APWr, Rep. 135, D 227, mf T78753, Chronica, s. 5. 
został cesarski dekret restytucyjny w obecności konsula namysłowskiego Caspara Schele, senatora Johanna Höckerta oraz szerokiej rzeszy ludności ${ }^{20}$.

Wspominany L. Joannston, pełniący dotychczas funkcję wikariusza (Curatus) franciszkańskiego kościoła, zwrócił klucze kanonikowi von Oberg, który z kolei przekazał je o. P. Mayowi, delegatowi i prokuratorowi prowincji czeskiej, jako znak pełnoprawnej restytucji nieruchomości miejskich prowincji franciszkańskiej na wieczność, najpierw we wnętrzu kościoła, następnie zaś klasztoru. Wszystko zatem, zarówno zabudowania jak i dawne prawa czy grunt, z wyjątkiem części ziemi naprzeciw bramy wrocławskiej, o której uczyniono transakcję, podlegało restytucji, której zakres określał i regulował wydany 8 stycznia 1677 r. we Wrocławiu instrument rozpoczynający się słowami: Der Römische Kayser auch zu Hungarn etc. Oryginał dokumentu przechowywano w Archiwum Prowincji, podobnie jak inny dekret wydany I2 maja I676 r. w sprawie spornego gruntu określanego mianem Burgplatz, który dawniej również przynależał do klasztoru ${ }^{21}$.

Kościół nasz namysłowski rozciaga się na długości 55 łokci i szerokości 33 łokci. Ma dwa dzwony oraz pięć ołtarzy: większy ku czci Wniebowzięcia NMP, pierwszy mniejszy po stronie Ewangelii ku czci NMP, następny św. Franciszka z Asyżu, po stronie epistoty ku czci św. Antoniego, czwarty poświęcony jest św. Piotrowi z Alkantary. Od poludnia znajduje się cmentarz. Klasztor namysłowski usytuowany jest w pobliżu północnego pasa murów miejskich, niedaleko bramy wrocławskiej, naprzeciw zamku na placu żydowskim, mierzy $w$ długości od południa na pótnoc 82 łokcie, w szerokości 53 tokcie. Restaurowany jest na mieszkanie dla 12. duchownych, jednocześnie z chórem kościoła i innymi, wspólnym kosztem wiernych Chrystusowi, który (koszt) zostat

\footnotetext{
20 Praementionato Anno Pater Theophilus May cum duobus Religiosis nostris Namslaviam ablegatus fuit; ubi interea in aedibus Admodum Reverendi Domini Laurentij Joannston Archi Presbyteri et Curati Namslaviensis hospitaliter receptus, et ab Eodem liberaliter sustentatus fuit per plures menses, qvoadusque eodem Anno sub Admodum Reverendo Patre Bernardo Sannig Ministro Provinciali Provinciae Boemiae, et totius Ordinis Diffinitore Generali vigore clementissimae Resolutionis Caesarea Leopoldi I. qua incipit: Wier Gaben aus eurem gehorsamen Brieff etc. data Viennae Anno 1675. die 21. Septembris in praefatum Conventum nostrum Namslaviensem Ejusque Ecclesiam et terminos Provinciae Boemiae fuisset restituta; qvae restitutio executioni mandata fuit octava Octobris ejusdem Anni, qvo die rejectis Patrum Conventualium praetensionibus, hora nona matutina Pater Patritius Pallet, qva Commissarius ad hunc effectum Delegatus ab A.R.P. Bernardo Sannig Ministro Provinciali, cum P. Theophilo May Protho - Praesidente, et quatuor Socijs Religiosis solemniter fuit reintroductus in Ecclesiam Assumptionis Beatae Mariae Virginis, et Conventum /: ad S. Petrum deinceps intitulatum a momorato P. Ministro Provinciali:/ per Caesareos Regiosqve Commissarios a Suprema Curia Silesiae legaliter Deputatos, videlicet Reverendissimum Dominum Casparum Henricum ab Oberg Cathedralis Ecclesiae Wratislaviensis Canonicum Seniorem, et Perillustrem Dominum Andream Fridericum Majorum Supremae Curiae Secretarium, qvibus Dominis Commissarijs ad coemeterium Ecclesiae nostrae Namslaviensis advenientibus, lecto prius Decreto Caesareo reintroductorio Ordinis nostri Namslaviam, praesente Nobili Domino Casparo Schele Consule Namslaviensi, et Joanne Höckert Senatore, maximaqve multitudine populi; APWr, Rep. 135, D 227, mf T78753, Chronica, s. 5-6/2.
}

21 Admodum Rev. Dominus Laurentius Joannston hactenus Curatus Ecclesiae istius, claves ejus Reverendissimo Domino ab Oberg Canonico lubens resignavit, qvas Is Patri Patricio Delegato Commissario, et Provinciae Procuratori tradidit pro signo restituta plena legitimae possesionis civilis Provinciae nostrae in perpetuum in eandem Ecclesiam: postmodum Conventus qvoqve, et omnes ejus metae ac jurisdictiones antiqvae /: excepta qvadam parte terrae versus portam Wratislaviense, circa qvam particularis facta est transactio:/ Ordini sunt restituta ab Iisdem D. D. Commissarijs. Super ejusmodi reintroductione extat solemne Instrumentum attestatorium totius functionis, debite peractae, incipit: Der Römische Kayser, auch zu Hungarn etc. datum Wratislaviae Anno 1677 die 8. Januarij. Originale reperitur in Archivo Provinciae, uti et aliud Decretum authenticum, confectum Anno 1676. die 12. May, in puncto controversiae areae vulgo: Burgplatz olim ad Conventum spectantis; APWr, Rep. 135, D 227, mf T78753, Chronica, s. 6/2-7. 
wsparty za prowincjalatu o. Bernarda Sanniga skrzętnie współdziałającymi ofiarami w latach 1676, 1677, 1678.

Zamieszkiwany jest od 1678 r. przez 12 braci żyjacych prosto, utrzymujacych się codziennym, niepewnym żebraniem ${ }^{22}$. Od strony wschodniej klasztor zamknięty jest ogrodem klasztornym, którego dtugość rozciagajaca się od klasztoru $w$ kierunku wschodnim wynosi 72 łokcie ${ }^{23}$, szerokość zaś, rozciagająca się w kierunku południowym od dawnego chóru kościoła, 76 stóp. Drugi fragment ogrodu ma dtugość 61, szerokość zaś 41 łokci. Od południowej strony klasztoru wznosi się oddzielony kościót; na wschód pokazuje się pewien nasz plac ze swoim ogrodem owocowym (sadem?), długi z pótnocy na południe na 82 łokcie i szeroki na 41 łokci. Na tym placu jest wykopane w części pótnocnej źródło najczystsze i najzdrowsze, niedaleko murów miejskich.

Zestawił to prawdomównym piórem o. Bernard Sannig, w tym czasie Minister Prowincjalny, $1678^{24}$.

\section{Plaszczyzny konfliktowe}

Na poziomie tekstowym z przedstawionego powyżej fragmentu kroniki konwentu opisującego w kontekście postępowania procesowego dzieje franciszkanów w Namysłowie wyznaczyć można pięć zasadniczych informacji, które naturalnie stanowią centra bardziej rozbudowanych sieci asocjacji i ciągów przyczynowo-skutkowych. Mają one, jak wskazywałem wcześniej, charakter argumentów potwierdzających prawa braci mniejszych czeskiej prowincji reformackiej do opisywanego klasztoru i kościoła. Zamykają się w następujących formułach:

I) Fundacja - Bracia Mniejsi prowincji saskiej otrzymali w I32I r. od śląskiego księcia Konrada Oleśnickiego grunt pod budowę kościoła i klasztoru

2) Zamiana - Od I5IO r. wskutek decyzji króla czeskiego potwierdzonej bullą papieża Klemensa VII oraz postanowieniami kapituły generalnej w miejsce minorytów saskich osadzono obserwantów prowincji czeskiej

\footnotetext{
22 Ecclesia nostra Nambslaviensis excurrit in longitudine ad ulnas 55. et mediam in luce, in latitudine ad 33. et mediam. Annotatio temporis Consecrationis Ejus injuria temporum escidit. Habet duas campanas, et altaria qvinqve" Majus Beatissimae Virginis Mariae Assumptae; primum minus ad Evangelium Beatae Virginis Mariae, alterum S. P. nostri Francisci, ad Epistolam, Divi Antonji, qvartum S. Petri de Alcantara. Ad meridiem sepitur Coemeterio nostrae Iurisdictionis. Conventus Nambslaviensis plantatus est prope murum civitatis Septemtrionalem, non procula porta Wratislaviensi versus Burgum in platea judica, continet in longitudine a meridie versus Septemtrionem metiendo 82. Ulnas; in latitudine 53. Restauratus est utcunqve pro habitatione 12 Religiosorum, una cum choro Ecclesiae, et alijs, et qvidem sumptibus communibus Christi fidelium. Sub Ministeriatu A. R. P. Bernardi Ministri Provincialis industriose concurrente Eleemosynis Anno 1676, 1677, 1678. Incolitur hoc Anno 1678 a 12 Fratribus sustentatis praecise qvotidiana dubia mendicatione; APWr, Rep. 135, D 227, mf T78753, Chronica, s. $6 / 2-7$.

23 W kopii praskiej napisano: 12 łokci.

24 A parte orientali sepitur horto Monastico, cujus longitudo excurrendo a Conventu versus Orientem consistit in 72 ulnis; latitudo in 76 penes qvem versus meridiem retro Chorum Ecclesiae excurrit, aliud fragmentum horti, longum versus meridiem 61. latum aute 41 ulnis; versus meridiem Monasterio aedificatur cernitur Ecclesia; ad Occidentem visitur quaedam nostra area cum suo pomario, longa a Septemtrione versus meridiem 82. ulnis, lata vero 41. ulnis; Fons limpidissimus et sanissimus effossus est in hac area versus Septemtrionem, non procul a muro Civitatis. Composuit haec veridico calamo Fr Bernardus Sannig pro tempore Minister Provincialis, 1678; APWr, Rep. 135, D 227, mf T78753, Chronica, s. 7.
} 
3) Opuszczenie - W wyniku postępu reformacji w I536 r. bracia opuścili klasztor, który od tego czasu użytkowany był jako szpital

4) Jałmużna - Uwypuklona została charakterystyczna dla zakonu franciszkańskiego rola jałmużny - z jednej strony w samym procesie wznoszenia obiektów po I32I r. czy ich późniejszej przebudowy w XVII w., z drugiej zaś w niemożliwości funkcjonowania w nim w okresie reformacji wskutek braku źródła utrzymania idącego w parze z brakiem nowych powołań

5) Restytucja - Wskutek działań procesowych klasztor i kościół decyzją cesarza przyznany został czeskiej prowincji franciszkańskiej

Oczywiście ekscerpcja informacji traktowanych w kategorii argumentów w postępowaniu rewindykacyjnym nasuwa równolegle konieczność określenia ich odbiorców. Sprecyzowanie jednostek lub grup adresatów przywołuje ponadto osadzone w kontekście historyczno-politycznym relacje, jakie łączyły i łączą ich z reformatami. W efekcie kompilacji tych danych formuje się niekiedy dość rozległa sieć konotacji i wzajemnych oddziaływań, w której centrum usytuowany jest konwent namysłowskich reformatów. Wydaje się ponadto, że wnioski wysnuwane w odniesieniu do tej konkretnej placówki mają charakter rozleglejszy, o ile nie uniwersalny dla wszystkich śląskich klasztorów reformackich tego czasu. Różnice w pewnych punktach - odbiorcach czy relacji z nimi - wprowadzają elementy wyróżniające poszczególne fundacje, nie czynią z nich jednak przypadków wykraczających poza granice obserwowanych zjawisk ${ }^{25}$.

Warto również podkreślić, że zarysowane powyżej kluczowe komunikaty, w części stają się płaszczyzną odbioru dla różnych adresatów, w zależności od przyjętego kontekstu. Sytuacja taka jest najbardziej widoczna w punkcie pierwszym, gdzie okoliczności fundacji aktywizują zarówno władcę, społeczność miejską, jak i zakon franciszkański, czy też ostatnim, stanowiącym formę treściowej kulminacji.

W pierwszej kolejności zatem uwidaczniają się spory wewnątrzzakonne oscylujące z jednej strony wokół różnic natury teologicznej, z drugiej zaś polityczno- administracyjnej. Kronika wprost określa zakonnych oponentów jako Patres Conventuales. Wydaje się jednak, że na przestrzeni trzech stuleci franciszkańskiej posługi w Namysłowie określenie to opisuje przynajmniej trzy płaszczyzny konfliktowe, które pokrótce scharakteryzuję niżej.

Kolejnym odbiorcą zbiorowym jest niewątpliwie społeczność miejska, która jako grupa obserwowana przez pryzmat kontaktów z franciszkanami na przestrzeni trzech stuleci otwiera trzy kierunki interpretacyjne. $Z$ jednej strony jako magistrat będący ośrodkiem decyzyjnym, urzędem w XVII-wiecznej dokumentacji procesowej występującej czasem jako strona. $Z$ drugiej strony działania rady miejskiej w stosunku do kościoła i klasztoru franciszkańskiego determinowały po części zmiany mentalno-wyznaniowe doby reformacji, co pozwala ująć w jednym punkcie drażliwe kwestie polemiki międzykonfesyjnej z protestantami, w stosunku do których autor kroniki nie kryje niechęci, widząc w nich przyczynę wygaśnięcia konwentu, co przejawia się również w pejoratywnych określeniach łączących reformację z toksyczną chorobą czy sektą. Trzeci kierunek rozważań wychodzi od pojęcia jałmużny, na którą kronikarz zwraca kilkakrotnie uwagę. Nie neguje faktu udzielania poparcia zakonowi przez władcę, wskazuje jednak z równą mocą, iż faktycznym źródłem

25 Mam tu na myśli chociażby różne okoliczności opuszczania klasztorów przez obserwantów w okresie reformacji - od klasycznego ,wymarcia” konwentu, przez dobrowolne opuszczenie, po wygnanie. 
utrzymania wspólnoty są ofiary składane przez wiernych, mające być w domyśle wyrazem społecznej akceptacji i udzielanego poparcia. Wspomniany władca, traktowany tu jako instytucja, nie stanowi w opisie kronikarskim osobnego odbiorcy, a raczej stronę, ostatnią instancję, do której odwołują się bracia, mogący liczyć na królewskie czy cesarskie wsparcie.

\section{Weryfikacja i wyjaśnienie}

Pozostaje ostatecznie konieczność konfrontacji przytaczanego wyżej fragmentu z innymi zachowanymi źródłami ${ }^{26}$. W związku z pewnym rozproszeniem informacyjnym, analizy wiarygodności zapisanych w kronice informacji dokonam, podporządkowując je poszczególnym odbiorcom. Pierwszym z nich zatem, i jak się wydaje najobficiej obudowanym racjami, są franciszkanie konwentualni.

Można wyznaczyć trzy zasadnicze etapy wewnątrzzakonnych sporów franciszkańskich. Ich sprecyzowanie chronologiczne i przedmiotowe warunkowane jest osadzeniem konkretnych sytuacji mających miejsce w oraz wokół klasztoru namysłowskiego, w szerszym kontekście obejmującym zmiany zachodzące zarówno w strukturze i formie funkcjonowania zakonu, jak i społeczności, w której bracia posługiwali. Najwcześniej, bo jeszcze w XIII w., zaistniał spór między minorytami prowincji saskiej i czesko-polskiej o przyłączenie kustodii złotoryjskiej i wrocławskiej, do której przynależał również klasztor namysłowski. Pomimo pewnych zmian w ciągu trwania sporu, w większości kustodie pozostawały w granicach prowincji saskiej ${ }^{27}$. Tak też było w I32I r., kiedy, jak wspomina kronika, Konrad Oleśnicki wydał pamiętny dokument fundacyjny, którego przedruk znalazł się m.in. w opracowaniu V. Greiderera ${ }^{28}$. Zgodnie z jego treścią bracia z klasztoru NMP koło Namysłowa (apud nostram civitatem) otrzymali działkę w mieście położoną naprzeciw placu/ulicy żydowskiej. W zamian za nią książę otrzymał działkę znajdującą się przy książęcej słodowni²9. W odniesieniu zatem do wyszczególnionego w kronice dokumentu fundacyjnego, w obliczu zachowania jego treści, można mówić o wiarygodnym potwierdzeniu. Podążając jednak dalej, to nie rok I32I jest jednak datą przybycia braci na ziemię namysłowską. Najstarsze wzmianki źródłowe o franciszkańskim klasztorze w Namysłowie pochodzą z I285 r., co pozwala ustalić przypuszczalny czas lokacji konwentu na ok. I284 r. ${ }^{30}$ Pierwotnie zatem klasztor prawdopodobnie położony był poza samym miastem lub na jego obrzeżach, na co wskazuje przytaczany fragment dokumentu fundacyjnego ${ }^{31}$. Interesujące wydaje się więc zwrócenie kronikarskiej uwagi jedynie na lokacje intra muros civitatis, bez sięgania do wcześniejszych wzmianek. Przypuszczam, że ma to swoje uzasadnienie w okolicznościach pisania kroniki i celu, jaki miała spełniać, a zatem historycznego udokumentowania praw

26 Z braku możliwości bezpośredniego korzystania z zasobu praskiego archiwum zmuszony jestem oprzeć większość swej pracy na opracowaniach - zarówno XVIII-wiecznych, jak i współczesnych, które jednak odwołują się do docelowego zbioru dokumentów.

27 D. Karczewski, Franciszkanie w monarchii Piastów i Jagiellonów w średniowieczu. Powstanie - rozwój-organizacja wewnętrzna, Kraków 2012, s. 43-71; J. Kłoczowski, op. cit., s. 36-43; J.B. Freed, Dzieje saskiej prowincji franciszkanów w XIII wieku, w: Franciszkanie, s. 215-216.

28 Przedruk w: V. Greiderer, op. cit., s. 832.

29 Namysłów. Z dziejów miasta i okolic, red. T. Wincewicz, Namysłów 2006, s. 41.

30 D. Karczewski, op. cit., s. 237. Tam też autor wymienia wspomniane źródła.

31 G. Wąs, Klasztory franciszkańskie w miastach śląskich i górnołużyckich XIII-XVI wieku, Wrocław 2000, „Acta Universitatis Wratislaviensis", No 2222, Historia 142, s. 61. 
własności do terenu i obiektów wybudowanych ze środków wiernych (ex communibus Christi fidelium eleemosynis). W związku z tym o samym konflikcie o kustodię kronika również nie wspomina, w ogóle nie wprowadzając do opisu na tym poziomie rozróżnień prowincjalnych.

Kwestii tych dotyka natomiast dalszy zapis, precyzujący saską przynależność prowincjalną minorytów. Informacja ta jest jednak podana w kontekście procesu zamiany. Zatem istotą komunikatu nie jest tu pierwotna prowincja, a raczej ta, która placówkę namysłowską przejęła. Innymi słowy, w postępowaniu rewindykacyjnym kluczową informacją jest przejęcie w I5IO r. przez czeskich obserwantów klasztoru namysłowskiego wskutek decyzji wyrażonej w liście Władysława Jagiellończyka skierowanym do magistratu. Decyzję tę potwierdzić następnie miały bulla papieża Klemensa VII z 29 listopada I523 r. ${ }^{22}$ oraz postanowienia kapituły generalnej w Burgos ${ }^{33}$, jak również dokument wydany przez Ludwika Jagiellończyka skierowany do biskupa wrocławskiego Jakuba, księcia legnicko-brzeskiego Fryderyka, księcia ziębickiego Karola i grona rajców miejskich, mieszczan etc. ${ }^{34}$ Wobec tego prócz samego faktu objęcia placówki przez czeskich obserwantów autor położył nacisk na możliwie wyraziste wyartykułowanie potwierdzenia jego zgodności z prawem - ze strony władcy, papieża oraz zakonu.

Wspomniane wydarzenia wpisywały się w szerszy kontekst polityczno-społeczny, w którym niebagatelną rolę odegrały zmiany zachodzące w łonie zakonu franciszkańskiego, związane $\mathrm{z}$ formowaniem się zakonu obserwanckiego. Uwidacznia się tu bowiem druga odsłona konfliktu wewnątrzzakonnego skoncentrowana wokół dwóch płaszczyzn: ideowej oraz politycznej. Na gruncie ideowym spór dotyczył stale dyskutowanej kwestii ubóstwa i postulatów ogólnej odnowy zakonu w duchu ściślejszego powrotu do źródeł i ideałów franciszkańskich. Równolegle formowały się nowe konwenty obserwanckie oraz niektóre konwentualne przyjmowały zreformowane statuty ułożone przez Jana Kapistrana i zatwierdzone przez papieża Marcina V w I430 r. Na Śląsku zatem, obok nowopowstających klasztorów obserwanckich połączonych z czasem w osobną prowincję czeską, funkcjonowały również saskie zreformowane konwenty martynian.

Nieco bardziej złożona jest płaszczyzna polityczna, wskazująca poniekąd odpowiedź na pytanie o przyczynę poparcia udzielanego obserwantom przez władcę. Władysław Jagiellończyk planował bowiem w taki sposób przeorganizować układ prowincjalny zakonu franciszkańskiego, aby jego granice pokrywały się z granicami Korony. Powstałaby wówczas jedna czeska prowincja, wykluczająca, np. na Śląsku, możliwość ingerencji obcych (saskich) czynników. Ponadto, uległyby zacieśnieniu wzajemne relacje franciszkanów z panującym na zasadzie konkretnej zależności, która w oczach władcy owocowałaby rozwinięciem funkcji klasztorów franciszkańskich o reprezentację polityki królewskiej w miastach ${ }^{35}$. Niosło to za sobą możliwość ingerencji dworu w wewnętrzne sprawy miast. Władysław próbował wprowadzić swój koncept za sprawą zabiegów dyplomatycznych zarówno z władzami

32 Przedruk w: S. Wrbczansky, op. cit., s. 24-26.

33 Przedruk w: ibidem, s. 21-23.

34 Przedruk w: ibidem, s. 20-21.

35 G. Wąs, op. cit., s. 126; eadem, Kształtowanie się nowych form świadomości religijnej w drugiej połowie XV i pierwszym dwudziestoleciu XVI wieku na przykładzie stosunków między radami miejskimi a klasztorami franciszkańskimi, „Sobótka”, 2000, 1, s. 14-15. 
zakonu, jak i Stolicą Apostolską ${ }^{36}$. Tę politykę wiernie kontynuował jego następca, Ludwik Jagiellończyk (I506-I526). Regularnie powtarzał żądania takiej reorganizacji prowincji, aby wszystkie klasztory franciszkańskie na Śląsku podległe były władzy prowincjała czeskiego. Przeciwko takim planom jednoznacznie opowiedziały się miasta śląskie, widzące w polityce królewskiej realną ingerencję w wewnętrzne sprawy swych społeczności, szczególnie w odniesieniu do klasztorów pierwszej formacji ${ }^{37}$.

Sytuacja uległa dodatkowej komplikacji po podziale zakonu franciszkańskiego w I5I7 r. i decyzji papieża, aby wszystkie wspólnoty reformowane złączyć w jedną nową organizację. Miały zatem w jeden zakon połączyć się saskie konwenty martynian oraz czeskie obserwantów. Rodziło to naturalnie regularne konflikty angażujące zarówno braci obu zakonów, władcę, jak i gminy miejskie. Przykładem głosu w sporze może być jedno z wielu pism Ludwika z dnia Io maja I520 r. przesłane do biskupa i wszystkich miast, w których znajdowały się klasztory, w którym król zażądał, aby franciszkanie tych kustodii [wrocławskiej i złotoryjskiej - M.M.] podporządkowali się czeskiemu prowincjałowi. W razie oporu groził im wygnaniem z kraju ${ }^{3}$.

Kwestia ta wydaje się być drugą płaszczyzną konfliktu minorycko- obserwanckiego. Wynikała ona z relacji: franciszkanie - król - miasto, z której każdy z trzech elementów oddziaływał na siebie nawzajem. Konflikt między saskimi franciszkanami reformowanymi i czeskimi franciszkanami obserwantami nie rozegrał się zatem na płaszczyźnie sporu o obserwację reguły franciszkańskiej, lecz był to spór władz świeckich: króla i miasta ${ }^{39}$.

Tak jak bezspornie można uznać za pewną drugą z wymienionych w kronice dat, gdyż faktycznie zachował się tekst bulli Klemensa VII, a także znane są postanowienia kapituły w Burgos, które, o czym nie wspomina kronika, zostały następnie powtórzone na kapitule w Parmie w 1529 r., tak przywołany rok I5Io budzi pewne wątpliwości. Zgodnie bowiem z treścią zapisu kronikarskiego już od tego roku czescy obserwanci objęli klasztor namysłowski w miejsce saskich konwentuałów. Brakuje jednak według mojej wiedzy źródeł potwierdzających ten fakt. Ferdinand Doelle, a za nim Gabriela Wąs sugerują raczej, iż jest to orientacyjna data przyjęcia przez saskich minorytów konstytucji marcińskich ${ }^{40}$. Był to proces raczej powszechny w saskiej prowincji franciszkańskiej, stanowiący formę blokującej reakcji na szybki przyrost zarówno liczby, jak i popularności rodzącego się od poł. XV w. odłamu obserwanckiego. Według F. Doellego na przyjęcie przez konwent namysłowski zreformowanych statutów wskazuje fakt ożywienia reformy w kilku śląskich klasztorach konwentualnych po kapitule kustodii wrocławskiej z dnia 20 lutego I508 r., podczas której omawiano kwestie jej przyjęcia. Wskazuje ponadto, że jest to bardzo prawdopodobne w kontekście przekazania miastu w dniu I5 marca I5IO r. przez klasztor, za zgodą kustosza

\footnotetext{
36 Kwestie te opisała szczegółowo G. Wąs: G. Wąs, Klasztory franciszkańskie, s. 125-140; eadem, Kształtowanie, s. 1-27; eadem, Franciszkanie-obserwanci na Śląsku w średniowieczu. Zarys historii, w: Bernardyni na Śląsku w późnym średniowieczu, red. J. Kostowski, Wrocław 2005, s. 21-50.

37 Eadem, Ksztaltowanie, s. 17.

38 Eadem, Klasztory franciszkańskie, s. 133.

39 Ibidem, s. 140.

40 Ich autorem był Jan Kapistran, którego celem przy tworzeniu konstytucji było zreformowanie całego zakonu franciszkańskiego $\mathrm{w}$ duchu powrotu do źródeł i pierwotnego ubóstwa, bez utrzymywania i rozwijania zaznaczającego się już wówczas podziału zakonu na tym tle. Braci konwentualnych, którzy przyjęli te statuty, określano mianem martinian bądź reformatów. F. Doelle, Die martinianische Reformbewegung in der sächsischen Franziskanerprovinz (Mittel- und Nordostdeutschland) im 15. und 16. Jahrhundert, Munster 1921, s. 68.
} 
wrocławskiego Benedykta z Lwówka i całej społeczności, słodowni i dalszych ogrodów ${ }^{4}$. Analogiczne działania miały miejsce w innych klasztorach minoryckich, przy których reformie swój wyraźny udział mieli przedstawiciele władz miejskich ${ }^{42}$. Nie wiem jedynie, czy była to praktyka wyróżniająca martynian, czy też nie stosowali jej obserwanci w myśl zaostrzonego ubóstwa.

Polemikę w stosunku do daty podjął jeszcze w XVIII w. V. Greiderer, wskazując, że jest ona zbyt wczesna i bardziej opisanemu wydarzeniu odpowiada rok I5I8. Autor odwołuje sie przy tym do tekstu bulli Klemensa VII, która jednak nie wskazuje na taką datę ${ }^{43}$. Co więcej, Greiderer zaznacza, iż ok. I5I8 r., jeśli nie wcześniej, klasztor został przyłączony do obserwanckiej prowincji św. Jana Chrzciciela, która była prowincją saską ${ }^{44}$. Postanowienie, aby to właśnie ta prowincja skupiała w sobie klasztory martynian z obszaru prowincji saskiej, podjęto podczas kapituły generalnej w Lyonie właśnie w I5I8 r.45

Od podobnych dywagacji odchodzi część badaczy ${ }^{46}$ i źródeł ${ }^{47}$, przyjmujących za datę objęcia placówki przez obserwantów bezpieczny rok I523, a zatem oficjalne potwierdzenie zamiany postanowieniami kapituły generalnej w Burgos oraz bulli Klemensa VII. Wskazuje sie ponadto, że zamiana miała być rodzajem dokonanej pod naciskiem biskupa reformy powodowanej nieobyczajnością namysłowskich minorytów.

$\mathrm{Na}$ tym etapie badań kwestia wyjaśnienia przywołania w kronice roku I5Io pozostaje otwarta. W obliczu jednak zasygnalizowanych okoliczności i propozycji interpretacyjnych zadać można pytanie, czy nie jest to celowe zakłamanie mające na celu przedłużenie bytności obserwantów w Namysłowie, co jak sądzę, mogło mieć również znaczenie w postępowaniu sądowym, gdzie niekoniecznie musiał być wystarczający argument „ostatniego użytkownika".

Do momentu opisu okoliczności zamiany włącznie, kronika posługuje się w stosunku do konwentualnych określeniami Fratres Minores, Patres Conventuales, podkreślając zarazem, jedynie przy akcie zamiany, ich przynależność prowincjalną (Provinciae Saxoniae), nie wspominając zaś w latach I5Io/I523-I675 o żadnym sporze. Konwentualni powracają dopiero w dalszej części opisu, przy wspomnieniu reskryptów cesarskich z września i października I675 r., gdzie kronikarz zaznacza, iż odrzucone zostały pretensje ojców konwentualnych. Jedynie z tego lakonicznego zdania można wnioskować o jakimkolwiek konflikcie na linii obserwanci - konwentualni o klasztor namysłowski w XVII w. Nie wydaje się przy tym, aby była to kwestia błaha, zastanawia zatem, zakładam, świadome pominięcie bardziej rozbudowanego opisu zdarzeń, które, jak wiadomo dzięki zachowanej dokumentacji w archiwum

41 Ibidem.

42 G. Wąs, Ksztaltowanie, s. 7-8.

43 Przedruk bulli w: S. Wrbczansky, op cit., s. 24-26.

44 V. Greiderer, op. cit., s. 832.

45 G. Wąs, Franciszkanie - obserwanci, s. 46.

46 Przykładem może być L. Teichmann, który wskazał faktycznie na rok 1523 jednak podkreślając, że zamiana odbyła się po wielu wysiłkach. L. Teichmann, Die Franziskaner-Observanten in Schlesien vor der Reformation, Breslau 1934, s. 41.

47 Repertorium Conventuum, Fundatorum, Capitulorum, Commissariorum, Provincialium atque Postarum, in Alma et Magna Provincia Boemiae s. Wenceslai D. et M. Fratrum Minorum Reformatorum ..., Brunnae 1734, b.pag. 
prowincji, będącej podstawą analiz K. Minarika, rozgrywały się na przestrzeni przeszło dwóch dekad.

K. Minarik wspomina, iż starania o objęcie klasztoru namysłowskiego podjęli już po wojnie trzydziestoletniej franciszkanie irlandzcy (Provincia Hiberniae), mający od I630 r. swoją siedzibę w Pradze ${ }^{48}$. Bez sukcesu jednak, wskutek wysunięcia podobnych roszczeń do cesarza Ferdynanda III przez czeskich braci mniejszych, na których korzyć cesarz już w I652 r. rozstrzygnął konflikt ${ }^{49}$.

Spór ten miał się stać następnie asumptem do wszczęcia działań restytucyjnych dla czeskich minorytów w stosunku do klasztorów w Środzie Śląskiej, Brzegu i właśnie Namysłowie. Przypuszczalnie pojawienie się nowej strony w procesie restytucyjnym stało się powodem decyzji cesarza z I654 r., by zgodnie z opisaną powyżej praktyką uczestnicy sporu przygotowali odpowiedni zbiór dokumentów będący prawną podstawą dla wydania wyroku ${ }^{50}$. K. Minarik wskazuje, że konflikt trwał do I659 r., następnie zaś rozgorzał ponownie w latach I667-I668. Z tego czasu pochodzi adnotacja w kronice miasta Namysłowa informująca, iż 30 grudnia 1667 roku wydane zostalo przez Królewski Krajowy Urząd we Wroctawiu i Antoniego Kemmlera pisemne wezwanie do odstapienia prowincjatowi Zakonu Franciszkanów i ponowne oddanie temu zakonowi polskiego kościoła i klasztoru, które przed reformacja należały do tego zakon ${ }^{5 \mathrm{I}}$. Nie wiadomo jednak, jaka prowincja miała te obiekty otrzymać.

Przełom w postępowaniu przyniósł rok 1674, kiedy czeski prowincjał reformacki Wilhelm Anton Brauczek (Brouček) zwrócił się do cesarza Leopolda I z prośbą o przyznanie klasztoru namysłowskiego, obiecując, iż wybuduje własnym nakładem na jego miejscu nowy. Zamiar ten poparł wymieniany również przez kronikę, Laurentius Joannston ${ }^{52}$, który w liście do cesarza z dnia 27 lutego 1675 r. dodatkowo ręczy za zgodę i poparcie całego miasta. Jak jednak podkreśla Minarik, nie była to cała prawda, gdyż rada miejska nie była temu przychylna ${ }^{53}$. Cesarz pismem z dnia 6 września 1675 r. powołał specjalną komisję, która miała rozstrzygnąć ostatecznie spór, co miało stać się faktem podczas wspólnego spotkania we Wrocławiu 8 kwietnia, kiedy minorytom przyznany został klasztor w Środzie Śląskiej, zaś reformatom w Namysłowie ${ }^{54}$. Dzięki osobistej interwencji kolejnego prowincjała, o. B. Sanniga, cesarz wyraził zgodę na szybsze osiedlenie braci w klasztorze, co wyrażone zostało pismem $\mathrm{z}$ dnia $2 \mathrm{I}$ września $1675 \mathrm{r}^{55} \mathrm{i}$, jak wspomina kronika, pozwoliło na powrót do klasztoru już 8 października.

\footnotetext{
48 Greiderer sytuuje te starania ok. 1650 r. V. Greiderer, op. cit., s. 832.

49 K. Minarik, op. cit., s. 24. Tam też autor powołuje się na bogaty materiał archiwalny.

50 Ibidem.

51 W. Liebich, Kronika miasta Namysłowa od jego założenia do czasów najnowszych opracowana przez W. Liebicha wedtug kroniki znajdującej się w archiwum miejskim, tłum. T. Harjasz, Namysłów (1862) 1995, s. 93.

52 Wg kroniki Liebicha, Laurentius Ivansthon von Hohenstein pochodzący z Koenigsbergu, określony jako bardzo gorliwy i wykształcony człowiek, w 1655 r. został mianowany na polecenie biskupa wrocławskiego i jego cesarskiej mości proboszczem i archiprezbiterem Namysłowa. Ibidem, s. 87. Funkcja archiprezbitera wynikała z potrydenckiej struktury administracji Kościoła katolickiego na Śląsku, w ramach której Namysłów należał do diecezji wrocławskiej, archidiakonatu Wrocław i archiprezbiteratu Namysłów. J. Mandziuk, Historia Kościoła katolickiego na Ślasku, t. II, Warszawa 1995, s. 170.

53 K. Minarik, op cit., s. 25.

54 Ibidem.

55 Przedruk w: S. Wrbczansky, op cit., s. 304-306.
} 
Opisany powyżej trzeci etap franciszkańskich konfliktów rozgrywających się wokół klasztoru w Namysłowie znów można określić mianem sporu minorycko- obserwanckiego (reformackiego). Kluczową zmianą jednak, jaka dokonała się na przestrzeni kilku stuleci rozwoju zakonu, jest fakt, iż do rywalizacji o klasztor stanęli co prawda przedstawiciele dwóch zakonów franciszkańskich, jednak prowincji zamkniętych granicami jednego kraju. Obecne zatem motywacje i spory natury politycznej, żywe jeszcze w XVI w., uległy poważnej zmianie wskutek, jak mniemam, włączenia Korony Czeskiej w obręb władztwa habsburskiego po I526 r., jak również zaangażowania w politykę konfesjonalizacji wszystkich zgromadzeń, które mogły przynieść oczekiwane efekty społeczno- polityczne.

Drugim $\mathrm{z}$ adresatów prawnej argumentacji reformatów jest szeroko rozumiane miasto. Zgodnie z wcześniej poczynioną uwagą, rozważania będę w tym punkcie prowadził na trzech obszarach: miasto reformacyjne, działania restytucyjne z perspektywy miasta oraz społeczność miejska źródłem utrzymania konwentu. Podobną logikę wypowiedzi sugeruje już wprowadzony w kronice podział na dwa zasadnicze człony - pierwszy, przywołujący opuszczenie klasztoru przez braci w I536 r. w kontekście rozwoju reformacji, oraz drugi, wzmiankujący rok I675, będący faktycznie punktem wyjścia dla szerszego zrelacjonowania bieżących dla autora wydarzeń związanych z procesem rewindykacji. O losach placówki w latach I536-I675 (I39 lat!) wiadomo w świetle kroniki jedynie tyle, iż budynek klasztorny zaadaptowano na szpital dla ubogich. I tak jak istotnie do lat pięćdziesiątych XVII w. najprawdopodobniej niewiele warte było odnotowania, tak wydarzenia poprzedzające radosne Te Deum z października I675 r. wydają się być wręcz kluczowe dla uzyskania pełniejszego obrazu procesu odzyskiwania obiektów namysłowskich. Głównym źródłem opisującym rzeczony okres jest kronika Namysłowa autorstwa W. Liebicha z I862 r., oparta na miejskiej kronice Frobeniusa. Zanim jednak pochylę się nad czasem habsburskiej rekatolicyzacji, wrócę na moment do przytoczonego $1536 \mathrm{r}$.

W Namysłowie już w I525 r. w kościele parafialnym św. św. Piotra i Pawła odbywały się nabożeństwa ewangelickie ${ }^{56}$. Kościół NMP zaś, wraz z klasztorem pozostawiono braciom ${ }^{57}$, którzy w części sami go opuścili, a w czesści wymarli. Ostatni z namysłowskich franciszkanów, nazywany przez ludzi Lorencem, który jeszcze w I556 r. deklarował chęć pozostania w dawnym klasztorze przekształconym na szpital ${ }^{8}$, zmarł i został pochowany w Biestrzykowicach ${ }^{59}$. Jak kontynuuje Liebich, po wymarciu zakonników, z klasztoru zrobiono szpital, a kościót pozostat na zakonne nabożeństwa ${ }^{60}$. Ze wspomnienia o bracie Lorencu można wnioskować, że przytułek powstał jeszcze za życia ostatnich obserwantów, co więcej, wskazuje na to kolejny wpis w kronice Liebicha informujący, że w I538 r. rada miejska pozwoliła wybudować browar zamkowy przy _ (podkr. M.M.), z czego autor wnioskował, że już przed tym czasem klasztor użytkowany był jako szpital ${ }^{6}$. Mateusz Goliński dodatkowo zaznacza, że przekształcenie klasztoru uczyniono po uzyskaniu rok wcześniej zgody od

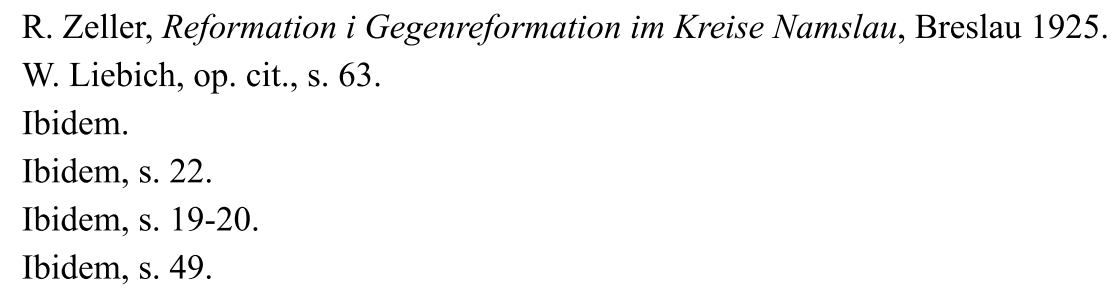


biskupa $^{62}$. Trudno jednoznacznie wskazać moment zakończenia działalności przytułku, wydaje się jednak, iż nie było to zbyt długo, gdyż całość, wraz z kościołem ${ }^{63}$, przeznaczono wkrótce na magazyn ${ }^{64}$.

Opisane powyżej działania wpisują się w swoistą praktykę postępowania z klasztorami opuszczanymi przez zakonników w dobie reformacji w śląskich miastach. Często pozostawiano im odpowiednią liczbę pomieszczeń, by mogli w swym klasztorze dokonać żywota, niejednokrotnie braci z okolicznych domów łączono w jednym obiekcie, uzyskane zaś budynki przeznaczano na szkoły, szpitale czy przytułki. Zdarzały się jednak również sytuacje siłowego pozbywania się zakonników na drodze ich wypędzania z miasta, co miało miejsce choćby we Wrocławiu czy Legnicy ${ }^{65}$.

Wspomniałem wcześniej o istotnych wydarzeniach rozgrywających się krótko po zakończeniu wojny trzydziestoletniej, mających decydujące znaczenie dla zaistnienia i powodzenia zjawiska, jakie można by określić mianem procesu restytucji klasztorów franciszkańskich na Śląsku.

Punktem zwrotnym w oficjalnym rozpoczęciu działań o charakterze rekatolicyzacyjnym na obszarze państwa habsburskiego była wojna trzydziestoletnia i kończące ją postanowienia pacis osnaburgensis. Przypominały one m.in. uformowaną w 1555 r. zasadę cuius regio eius religio, stanowiącą prawną podstawę kontrreformacyjnych działań władcy na swych terenach dziedzicznych. Ostrze polityki konfesjonalizacyjnej ostatecznie ukierunkowane zostało po roku I620. Ów „,cesarski katolicyzm” Habsburgów stat się wnet synonimem kontrreformacyjnej postawy z punktu widzenia politycznej racji stanu, a religijne porządki miały dopomóc w realizacji mocarstwowych zamierzeń; to ostatnie stato się szczególnie widoczne po I620 $r$., kiedy po zwycięstwie nad czeskimi reformatorami i obrońcami narodowych wolności, już bez żadnych oporów Habsburgowie realizowali swój program kontrreformacyjny ${ }^{66}$. W jego ramach mieściła się przeprowadzana $\mathrm{w}$ latach pięćdziesiątych na terenie całego władztwa habsburskiego akcja redukcji świątyñ ${ }^{6}$. Jak wskazywałem wyżej, cesarz przyznał obserwantom placówkę namysłowską już w I652 r., jednak oficjalny proces przejmowania obiektów realizowany był według zasad cesarskiego rozkazu ze stycznia I653 r. W jego myśl w księstwach dziedzicznych odpowiednio powołane komisje redukcyjne miały prawo odbierać przejęte w dobie reformacji kościoły i przywracać je katolikom. W Namysłowie już 27 lipca wszyscy ewangeliccy kapłani, wikariusze, jak też stużba szkolna musiała się stawić w ratuszu $w$ Namysłowie, aby wystuchać cesarskiego rozkazu, wedlug którego w catej namysłowskiej okolicy pod kara zabroniono odbywanie mszy św., a po uplywie 6 tygodni $i 3$ dni mieliby opuścić stanowiska proboszczów. I2 lipca zostat do ewangelickiego duchowieństwa wydany rozkaz Księstwa Wrocławskiego, że pod groźba kary przy opuszczaniu swoich parafii maja zostawić kościelne klucze i rejestry kościelne. Wydaje się, że nietolerancyjny rozkaz wykonany

\footnotetext{
62 Namystów, s. 137.

${ }^{63}$ Die Bau- und Kunstdenkmaeler des Kreises Namslau, hrsg. K. Degen, Breslau 1939, s. 155.

64 Namystów, s. 137.

65 G. Wąs, Klasztory franciszkańskie, s. 163.

66 J. Kopiec, Stosunki wyznaniowe na Ślasku za panowania Habsburgów, w: Śląsk za panowania Habsburgów, red. W. Lesiuk, M. Lis, Opole 2001, s. 89.

67 O stanie diecezji w tym okresie: J. Kopiec, Relacje biskupów wroctawskich “ad limina” z XVII I XVIII wieku, „Nasza Przeszłość”, 68, 1987, Kraków, s. 93-132.
} 
zostat $w$ Namystowie dopiero $w$ następnym roku ${ }^{68}$. Już bowiem w I654 r. katolicka komisja redukcyjna, w której skład wchodził m.in. wspominany w kronice konwenckiej kanonik Kaspar Heinrich von Oberg, przejęła namysłowskie świątynie, w tym kościół franciszkański (określany również mianem polskiego) i po ponownym poświęceniu, przekazała w tymczasowy zarząd trzem mnichom franciszkańskim ${ }^{69}$. Nie wiadomo niestety, jakie imiona nosili, ani skąd przybyli owi zakonnicy. Niewykluczone, iż byli to wspominani w poprzednim passusie bracia mniejsi prowincji irlandzkiej, którzy właśnie w latach pięćdziesiątych mieli czynić starania o przejęcie klasztoru w Namysłowie ${ }^{70}$.

Działania te otworzyły dla zakonu franciszkańskiego możliwość ubiegania się o zwrot przejętych wcześniej zabudowań, co, jak wskazywałem wyżej, bracia wytrwale czynili. Według jednak adnotacji Liebicha, franciszkanie pojawiali się w Namysłowie nie tylko, że wcześniej, ale również częściej aniżeli sugerowałaby to kronika konwentu. Prócz wspomnianych wyżej bracia, tym razem z klasztoru nyskiego, a zatem reformaci, mieli przybyć do Namysłowa w I670 r. celem dokonania przegladu polskiego kościoła i klasztoru. Pod rokiem I67I zaś Liebich zanotował: Franciszkańscy zakonnicy wznieśli klasztor na placu, gdzie wcześniej stał kościół katolicki. Ta informacja jest dla mnie jednak zupełnie niejasna.

Kontynuując opis powrotu franciszkanów czyniony z perspektywy miasta, Liebich zanotował, że II lutegoI675 r. na probostwo przybyło 2 zakonników Minorytów, Bazyleusz i Nirbertus i przeprowadzili końcowe opróżnianie klasztoru, który od 1536 roku wykorzystywany byt na przytułek $i$ kazali rozebrać stajnie zbudowane dla szpitalnego bydta, częściowo rozebrać założone krużganki, a częściowo uprzatnać. Magistrat po tym zbudowat dla biednych inny przytułek obok aresztu ${ }^{71}$. Przekazana informacja częściowo pokrywa się ze źródłami, bowiem faktycznie w i675 r. przybyli do Namysłowa o. Theophilus May, o. Basilius oraz o. Nirbertus wraz z dwoma braćmi laikami ${ }^{72}$. Błędne jest określenie ,,minoryci" oraz pominięcie o. Theophilusa. Nie wiadomo ponadto, czy było to w lutym, będąc jednak wiernym kronice konwentu, bracia mieli przebywać w gościnie u L. Joannstona przez wiele miesięcy, które minęły do wprowadzenia się ich do klasztoru w październiku. Zastanawiające jest jedynie, że już wówczas reformaci mieli prowadzić prace porządkowe w klasztorze, do którego oficjalnie jeszcze nie otrzymali praw gwarantowanych dopiero cesarską rezolucją z 2I września.

Swoistą kontynuacją wątku „miejskiego” jest odniesienie się do zaprezentowanego w kronice konwentu opisu uroczystej ceremonii oficjalnego przekazania zabudowań franciszkanom. Opis kronikarski pokrywa się z relacją sporządzoną przez cesarskiego komisarza pod datą 17 października I675 r., podpisaną przez Kaspara Heinricha von Oberg oraz Friedricha Magirusa von Logau ${ }^{73}$. Liebich z kolei ogranicza się zapisku: I9 października dotychczasowy klasztor poświęcony św. Dziewicy, został poświęcony czci św. Piotra z Alikante ${ }^{74}$.

\footnotetext{
68 W. Liebich, op. cit., s. 88.

69 Ibidem, s. 89.

70 V. Greiderer, op. cit., s. 832.

W. Liebich, op. cit., s. 93.

S. Wrbczansky, op. cit., s. 305.

Przedruk w: S. Wrbczansky, op. cit., s. 306-307.

W. Liebich, op. cit., s. 93.
} 
Sądząc po fragmencie reformackiego kodeksu oraz przywołanej relacji komisarza cesarskiego, przekazanie kluczy i dokumentów własnościowych miało charakter niezwykle uroczysty, angażujący, jak wspominałem na początku, zarówno członków nowego konwentu, władze zakonne, miejskie, duchowne oraz wiernych. Stanowiąc kwintesencję trwającego kilkanaście lat procesu restytucyjnego, musiało otrzymać odpowiednią oprawę i rozgłos, którego echa pozostały na kartach kroniki. Patrząc nawet czysto technicznie, proporcjonalnie opis wydarzeń roku 1675 wypełnia niemal dwie z czterech stron ustępu. Wynika to naturalnie z wagi, jaką autor kroniki przykładał do tej części dziejów powstania konwentu, które stanowią zarówno kulminację działań rewindykacyjnych, jak i uzasadnienie retrospektywnego sięgania do wszystkich wcześniej zamieszczanych faktów. Nie tylko więc poprzez osadzenie odbiorcy w wydarzeniach roku I675 jako punktu wyjścia pełni ów opis funkcję wyjaśniającą, ale także w kontekście całej historii z lat I32I-I675 stanowi jego logiczne uzasadnienie.

Deskrypcję wydarzeń z dnia 8 września I675 r. kończy przywołanie normatywnych regulacji ustalających zasady koegzystencji reformatów z namysłowskim magistratem, ale również, wskutek czynienia starań o odzyskanie części gruntu z dawnej jurydyki książęcej, której właścicielem w latach $1533-1703$ była rada miejska Wrocławia ${ }^{75}$, z magistratem wrocławskim. Zarówno zatem instrument reintrodukcyjny z dnia 8 stycznia $1676 \mathrm{r}^{76}$, jak i dekret z dnia I2 maja I676 r.77 regulujący kwestie własności gruntu określanego jako Burgplatz znajdują się w formie odpisów w dalszych częściach pierwszego rozdziału kroniki.

Ostatnim, sygnalizowanym aspektem relacji klasztor - miasto jest zagadnienie jałmużny. Pojawia się ono w przytaczanym fragmencie trzykrotnie. Miejsce usytuowania tych zaznaczeń wydaje się nie być przypadkowym. Każdorazowo bowiem informacja ta stanowi jakby stały element komunikatu formułowanego na zasadzie sprytnego zabiegu retorycznego, który zestawia przy powiadomieniu o nowym etapie działalności placówki kluczową rolę władcy jako ośrodka decyzyjnego właśnie z podawanym jakby dla równowagi zaznaczeniem o jałmużnie. Istotnie, to władca jest tym, który daje, przywraca, roztacza prawną opiekę, jednak w zgodzie z zakonnym charyzmatem mendykanckim to ofiary wiernych leżą u podstaw egzystencji konwentu. Stąd kronikarz wspomina zarówno o budowie czy odbudowie obiektów ze składem wiernych, jak również w kontekście reformacji, pisze o opuszczeniu klasztoru wskutek braku środków utrzymania oraz nowych powołań.

W realiach XVII-wiecznej restytucji klasztoru argument jałmużny powraca ponownie w zestawieniu z protekcyjną rolą cesarza. Ciekawe, że użyte w tekście słowo qvidam można tłumaczyć zarówno jako ,jednakże” jak i „,bez wątpienia”, „właśnie”. W zależności od przyjętej wersji można odczytać w różny sposób intencję i nacechowanie zwrotu, który, dla przypomnienia, brzmi: Restauratus est [conventus Namslaviensis - M. M.] utcunqve pro habitatione I2 Religiosorum, una cum choro Ecclesiae et alijs, et qvidem sumptibus communibus Christi fidelium ${ }^{78}$. Ponadto kronika wyraźnie podkreśla, że klasztor budowany był ze społecznych składek klasztorów całej prowincji przy szczególnym zaangażowaniu

75 Namystów, s. 142.

76 Przedruk: S. Wrbczansky, op. cit., s. 307-308.

77 Przedruk: ibidem, s. 309-311.

78 APWr, Rep. 135, D 227, mf T78753, Chronica, s. 7. 
i pomocy o. B. Sanniga. Wydaje się, że było to działanie powtarzane przy kolejno odbudowujących się klasztorach prowincji ${ }^{79}$.

Prace prowadzone nad odbudową i przebudową kościoła i klasztoru namysłowskiego warunkowane były z jednej strony obietnicą złożoną przez prowincjała Benkowicza, z drugiej zaś faktyczną koniecznością. Zgodnie z informacją zaczerpniętą z dokumentów wizytacyjnych z I666 r., kościół był praktycznie zupełnie zniszczony, łącznie ze sklepieniami, zaś sprzed czasów reformacji zachował się tylko jeden ołtarz Wniebowzięcia NMP ${ }^{80}$. Funkcje magazynowe czy szpitalne nie służyły bynajmniej utrzymaniu dobrej kondycji średniowiecznych zabudowań. Ostatnią częścią opracowywanego przeze mnie fragmentu jest opis namysłowskich zabudowań franciszkańskich z ok. I678 r. Jest to źródło o tyle cenne, że już w I682 r. i potem jeszcze przynajmniej raz w ciągu XVIII w. cały kompleks płonął, w związku z czym uchwycony piórem kronikarza obraz jest jedynym śladem po pierwszym etapie modernizacji obiektów w duchu baroku. Uzupełniają go późniejsze adnotacje Wrbczanskiego czy Greiderera, a w końcu grafika B.B. Wehrnera. Wiadomo zatem, że po odbudowie z pożaru klasztor liczył 82 łokcie długości i 53 szerokości. Zgodnie z potrzebami reformackiej egzystencji w klasztorze znajdowało się jedno dormitorium, 24 cele, szpital, infirmeria, trzy repozytoria czy biblioteka. W części wschodniej usytuowany był ogród $(72 \times 76 \text { łokci })^{81}$. Kościół powtórnie konsekrowany w I7ı6 r. wypełniało już nie pięć, a osiem ołtarzy, przy których tworzeniu brał udział m.in. słynny śląski malarz barokowy Johann Jacob Eybelwieser ${ }^{82}$.

Są to już jednak zagadnienia, które, podobnie jak krąg donatorów czy formy włączania się reformatów w życie społeczności namysłowskiej, stanowią osobny rozdział dziejów klasztoru franciszkańskiego.

Reasumując, zaprezentowany fragment namysłowskiej kroniki konwentu reformatów stanowi interesujące źródło pozwalające badać i konstruować wizję minionej rzeczywistości nie tylko poprzez dostarczane dane faktograficzne, ale również za sprawą interpretacji formy i treści przekazu w konkretnym kontekście. Tłem kontekstualnym, stanowiącym w istocie zarówno punkt wyjścia, jak i ośrodek kulminacji opisywanego wycinka historii był proces restytucji franciszkańskich zabudowań w Namysłowie prowadzony w drugiej połowie XVII w. Przyjęcie tak jednoznacznie określonego podłoża, sytuacji, pozwoliło dokonać próby interpretacji przywoływanych faktów z dziejów namysłowskich franciszkanów, mając na uwadze możliwość ich wykorzystania w postępowaniu rewindykacyjnym.

Możliwe jest jednak, że dobór faktów nie był zdeterminowany chęcią uwypuklenia prawnej podstawy posiadania obiektów przez reformatów. Nie można wykluczyć, że jest to jedynie wynik kwerendy, która nie przyniosła innych niż oglądane wyników w związku z czym kronikarz, czy był nim sam prowincjał B. Sannig czy każdy inny konwencki historyk, zestawił je w porządku chronologicznym, nie przywiązując do nich większej aniżeli historyczna roli. Być może taki, nieskomplikowany był przebieg procesu twórczego kroniki reformatów namysłowskich. Po cichu jednak liczę, że prawdziwe motywacje twórców wykraczały daleko

\footnotetext{
79 We wrocławskiej kronice konwenckiej adnotacje o wysokościach donacji składanych przez poszczególne klasztory stanowią ok. 1/3 analogicznych wpisów. NA Praha, RF, 456, kodeks 64, Archivum Conventus Wratislaviensis noviter descriptum Anno MDCCL, s. 73-83.

80 Die Bau- und Kunstdenkmaeler, s. 155.

81 S. Wrbczansky, op. cit., s. 307-308; V. Greiderer, op. cit., s. 833.

82 NA Praha, RF, 453, kodeks 60, Chronica, b.p.
} 
poza poprawność historyczną. W efekcie bowiem zawsze subiektywnego wyboru źródeł czy formy zestawienia informacji, a tu dodatkowo ukierunkowanego w sposób narzucający konkretną interpretację źródło kronikarskie staje się nie tylko klasycznym nośnikiem treści faktograficznych, ale nadto obrazem mentalności społeczności odpowiedzialnej za jego powstanie. Więcej, pozwala zadać sobie pytanie o cel konstrukcji tego określonego obrazu przeszłości - zarówno na płaszczyźnie świadomości historycznej odbiorcy XVII i XVIII w. jak i współczesnego.

\section{The revival of the Monastery of Reformed Franciscans in Namystów in the 17th century in the light of the first chapter of the convent's chronicle Summary}

The goal of this study is, on the one hand, to outline the circumstances leading to formation of the convent of Reformed Franciscans in Namystów in I675, and on the other hand, to show the way of conducting historiographical narrative in the chronicle sources of Reformed Franciscans. This issue is particularly interesting in the context of repossession activities, which have been conducted by the St. Wenceslaus' Czech province of Reformed Franciscans since the beginning of the 17 th century, aiming at the return of observance monasteries confiscated in the era of the Reformation and, in this way, rebuilding the structures of the province. The goal of systematized vision of the past was, on the one hand, to consolidate the young province, on the other hand, to demonstrate historical rights of Czech Reformed Franciscans to particular monastic houses. An example of such narrative, coordinated by one of the provincials, Fr Bernard Sannig, is a chronicle of the convent of Reformed Franciscans in Namysłów, which was, with 9 other monasteries, a Silesian part of Czech province.

Keywords: Namyslow, Reformed Franciscans, chronicle, Silesia, recatholization

Nota o Autorze: mgr Marcin Musial (ur. 1989 r. we Wrocławiu) W 2013 r. ukończył studia historyczne na Uniwersytecie Wrocławskim i rozpoczął studia doktoranckie, podczas których bada nowożytne dzieje i kulturę zakonu franciszkanów reformatów na obszarze Śląska, korzystając z metod wypracowywanych na gruncie kultury pamięci i studiów nad organizacjami. Od 20 or r. realizuje również studia w zakresie historii sztuki na Uniwersytecie Wrocławskim. 